\title{
Genetic Control of Resistance to Tan Necrosis Induced by Pyrenophora tritici-repentis, Races 1 and 2, in Spring and Winter Wheat Genotypes
}

\author{
P. K. Singh and G. R. Hughes
}

Department of Plant Sciences, 51 Campus Drive, University of Saskatchewan, Saskatoon, SK, S7N 5A8, Canada. Accepted for publication 30 August 2004.

\begin{abstract}
Singh, P. K., and Hughes, G. R. 2005. Genetic control of resistance to tan necrosis induced by Pyrenophora tritici-repentis, races 1 and 2, in spring and winter wheat genotypes. Phytopathology 95:172-177.

The symptoms of tan spot of wheat, caused by Pyrenophora triticirepentis, include a tan necrosis component and an extensive chlorosis component. Since tan spot has become the major component of the leafspotting disease complex of wheat in western Canada, the need for resistant cultivars has increased. This study was conducted to determine whether the resistance to tan spot found in a diverse set of spring and

repentis race 1 and race 2 was determined, under controlled environmental conditions, for spring wheat genotypes Erik and 86ISMN 2137 and winter wheat genotypes Hadden, Red Chief, and 6B-365. Plants were inoculated at the two-leaf stage and disease reaction was assessed based on lesion type. Tests of the $F_{1}$ and $F_{2}$ generations, and of $F_{2: 3}$ and $F_{2: 8}$ families, indicated that one recessive gene controlled resistance to the necrosis component of tan spot caused by both race 1 and race 2 in each cross studied. Lack of segregation in crosses between the resistant cultivars indicated that the resistance gene was the same in all of the cultivars.
\end{abstract} winter wheat genotypes was due to resistance genes not previously reported. The genetic control of resistance to necrosis induced by $P$. tritici-
Additional keywords: host resistance, Triticum aestivum.
Tan spot of wheat, caused by the fungus Pyrenophora triticirepentis (Died.) Drechs., is a worldwide disease that causes loss both in quality and quantity of grain $(5,14)$. Increases in the incidence and severity of tan spot have been attributed to changes in cultural practices including shifts from conventional tillage and stubble burning to conservation tillage systems, shorter crop rotations, continuous wheat cultivation, and use of susceptible cultivars $(5,6,15)$.

The tan spot disease syndrome consists of two phenotypically distinct and independent symptoms: tan necrosis and extensive chlorosis (20). Resistance is expressed as small, dark brown lesions that do not increase in size, while susceptibility is expressed as dark brown spots surrounded by tan necrosis and/or extensive chlorosis that may involve the entire leaf. Necrotic lesions are well defined and tan in color, while chlorotic lesions are less well defined and exhibit gradual yellow discoloration (20).

Initially, isolates of $P$. tritici-repentis were grouped into four pathotypes based on their ability to induce tan necrosis and/or extensive chlorosis $(22,23)$. Later Lamari et al. (24) proposed a racebased system to describe isolates of $P$. tritici-repentis and currently 11 races of $P$. tritici-repentis have been identified $(2,3,25,26)$.

Resistance to tan spot of wheat has been reported to be inherited quantitatively $(10,13,28,29)$ and qualitatively $(4,8,9,17$, 18). A gene, tsn1, controlling resistance to the necrosis component of tan spot has been located on chromosome 5BL $(12,30)$. Recent genetic studies $(8,17)$ have indicated that single recessive genes control resistance to necrosis caused by races 1 and 2 in durum and in common wheat. Because these results suggest a narrow genetic base for resistance to tan spot in wheat, this study was initiated using a diverse range of winter and spring cultivars

Corresponding author: G. R. Hughes; E-mail address: geoff.hughes@ usask.ca

DOI: 10.1094/PHYTO-95-0172

(c) 2005 The American Phytopathological Society to identify new resistance genes. The specific objectives of this study were to (i) study the genetic control of resistance to the necrosis component of tan spot caused by $P$. tritici-repentis, race 1 and race 2; (ii) determine the allelic relationship among the resistance gene(s) identified; and (iii) determine the relationship between the genes controlling resistance to necrosis caused by race 1 and race 2 .

\section{MATERIALS AND METHODS}

Population development. Seven wheat genotypes, selected for this study based on their reaction to race 1 and race 2 of $P$. triticirepentis (Table 1), were used to produce 16 cross populations. Each $F_{1}$ plant grown to produce $F_{2}$ seed was harvested separately, and the $F_{2}$ populations derived from each $F_{1}$ plant were tested individually for disease reaction. All $\mathrm{F}_{2: 3}$ families, $\mathrm{F}_{2: 4}$ families, and $\mathrm{F}_{2: 8}$ families were produced by single seed descent.

Inheritance studies. Inheritance studies involved testing for tan spot reaction in crosses between resistant and susceptible genotypes (R/S crosses). The $F_{1}$ and $F_{2}$ generations and the $F_{2: 3}$ families were screened with race 1 isolate Ptr 200 and race 2 isolate Ptr 92-164 to determine the inheritance of resistance to the necrosis component of tan spot. $\mathrm{F}_{2: 4}$ families were also tested with race 2 . A family size of 16 to 18 plants was used to give a $99 \%$ probability of correctly distinguishing between a segregating and a nonsegregating family if a single gene controlled resistance (19). However, since the cross Glenlea/6B-365 segregated for both the necrosis and the chlorosis components when tested with race 1 , it was hypothesized that resistance to tan spot in this cross was controlled by two genes. In this cross, at least 36 plants per $\mathrm{F}_{2: 3}$ family were tested to ensure a $90 \%$ probability of correctly identifying all genotypic classes (19). A minimum of 60 families per cross were tested.

Allelism studies. Allelic studies involved testing for tan spot reaction in crosses between resistant $\times$ resistant genotypes $(R / R$ 
crosses) and between susceptible $\times$ susceptible genotypes (S/S crosses). The six possible crosses among the resistant genotypes Red Chief, 86ISMN 2137, Erik, and Hadden and the cross between susceptible cvs. Kenyon and Glenlea were studied. $F_{1}$ and $F_{2}$ plants and $F_{2: 3}$ families (12 plants per family) were screened with race 2 . At least $40 \mathrm{~F}_{2: 3}$ families per cross were tested.

$\mathrm{F}_{2: 8}$ lines of the cross Erik/Glenlea were tested with race 1 and race 2 to establish the relationship between the genetic control of resistance to the necrosis component of tan spot caused by these two races. Eighty lines with at least 16 plants per line were screened with each race.

Inoculum production. Isolates Ptr 200 (race 1), provided by G. R. Hughes, University of Saskatchewan, and Ptr 92-164 (race 2), provided by L. Lamari, University of Manitoba, were used in this study. Single-spore cultures were produced for each of the two isolates and stored at $4^{\circ} \mathrm{C}$ for inoculum production.

Inoculum was produced using a modification of the method of Lamari and Bernier (20). Mycelial plugs, $0.5-\mathrm{cm}$ diameter, from the stock cultures were transferred to $10-\mathrm{cm}$ petri plates containing V8-potato dextrose agar (PDA) $(150 \mathrm{ml}$ of V8 juice, $10 \mathrm{~g}$ of PDA, $10 \mathrm{~g}$ of agar, $3 \mathrm{~g}$ of $\mathrm{CaCO}_{3}$, and $850 \mathrm{ml}$ of distilled water). These cultures were incubated in the dark at 20 to $22^{\circ} \mathrm{C}$ for 6 days. The plates were then flooded with sterile distilled water, the mycelium was flattened with the base of a sterile test tube, and excess water was poured off. The plates were incubated under continuous light at room temperature for 2 days to induce conidiophore production, and then for 1 day in the dark at 15 to $16^{\circ} \mathrm{C}$ to induce conidial production.

To produce inoculum, the plates were flooded with distilled water and the conidia were suspended in the distilled water by gently brushing the mycelium with a camel-hair brush to dislodge the conidia from the conidiophores. Tween 20 (polyoxyethylene sorbitan monolaureate) was added to the spore suspension (5 to 7 drops per liter), and the spore concentration was adjusted to 3,000 conidia per $\mathrm{ml}$.

Disease screening. To optimize uniform emergence, seed of the populations to be screened and the parental genotypes, which were grown as resistant and susceptible checks and were pregerminated, and seeds at a similar stage of germination were planted in 6-in.-diameter pots containing soilless mix (Redi-Earth, W.R. Grace and Co. of Canada Ltd., Ajax, ON, Canada). In the allelism studies, 12 seeds per pot were planted, whereas 9 seeds per pot were planted in all other studies. All disease tests were conducted using a completely randomized design. Using a hand sprayer, plants at the two-leaf stage were sprayed with a conidial suspension of the appropriate isolate until runoff. Following inoculation, the seedlings were incubated for $24 \mathrm{~h}$ in continuous leaf wetness in a mist chamber located in a growth room at $22 / 17^{\circ} \mathrm{C}$ (day/night) with a $16 \mathrm{~h}$ photoperiod.

Eight days after inoculation, seedlings were rated for reaction to tan spot using the 1 to 5 lesion type rating scale developed by
Lamari and Bernier (20). Plants with ratings of 1 to 2 were considered resistant, and those with ratings of 3 to 5 were considered susceptible.

\section{RESULTS}

Erik, Red Chief, Hadden, and 86ISMN 2137 were resistant to both the necrosis and the chlorosis component. However, these genotypes differed in the level of resistance expressed. Erik and Red Chief were rated 1 and 86ISMN 2137 was rated 2, whereas Hadden was more variable, giving a 1 to 2 rating for resistance to the necrosis component. Glenlea and Kenyon consistently produced susceptible necrotic reactions (ratings of 4 to 5). Line 6B-365 was resistant to necrosis but susceptible to the chlorosis component.

Genetics of resistance to necrosis caused by race $2 . F_{1}$ plants of all eight R/S crosses studied were susceptible, indicating that resistance was recessive (Table 2). These plants showed a range of susceptible reaction types (ratings of 3 to 5 ), although the $F_{1}$ plants of crosses involving resistant parent Hadden were less susceptible than $\mathrm{F}_{1}$ plants of the other crosses.

The $F_{2}$ generations of these $R / S$ crosses segregated in a 1 resistant $/ 3$ susceptible ratio indicating single gene control and confirming that resistance to necrosis was recessive (Table 2). The $\mathrm{F}_{2: 3}$ family segregation of 1 homozygous resistant/2 segregating/ 1 homozygous susceptible supported the hypothesis of monogenic control of resistance (Table 3). This hypothesis was further confirmed by the $\mathrm{F}_{2: 4}$ family segregation which fitted a 3 homozygous resistant/2 segregating/3 homozygous susceptible ratio in each cross studied (Table 4). All $F_{1}$ and $F_{2}$ plants and the $F_{2: 3}$ families of the $\mathrm{S} / \mathrm{S}$ cross between susceptible cvs. Kenyon and Glenlea were susceptible, indicating that both parents share the same susceptibility gene(s) (Tables 2 and 3 ).

$\mathrm{F}_{1}$ plants of the six possible $\mathrm{R} / \mathrm{R}$ crosses among the four resistant parents were resistant to race 2 . However, while most $F_{2}$ plants of these crosses were resistant, a few plants showed a moderately susceptible reaction (rating 3 ). With the exception of cross Hadden/Red Chief, $\mathrm{F}_{2}$ plants of each cross involving only resistant genotypes did not fit a 15 resistant/1 susceptible segregation ratio, suggesting that each genotype carried the same resistance gene (Table 2). None of the $\mathrm{F}_{2: 3}$ families of the $\mathrm{R} / \mathrm{R}$ crosses studied were susceptible, thus confirming the presence of the same resistant gene among the resistant parents (Table 3). The $\mathrm{F}_{2}$ generation of the cross Hadden/Red Chief segregated in a 15 resistant/1 susceptible ratio indicating that Hadden and Red Chief possessed different resistance genes. This hypothesis could not be verified because seed of $F_{2: 3}$ families of the cross Hadden/Red Chief had not been produced.

Genetics of resistance to necrosis caused by race $1 . F_{1}$ plants of the R/S crosses Erik/Glenlea and Hadden/Glenlea were susceptible to necrosis indicating that resistance to the necrosis component of tan spot was recessive (Table 2). Segregation of the

TABLE 1. Growth habit, origin, reaction to Pyrenophora tritici-repentis race 1 and race 2, and pedigrees of the cultivars selected for study of the genetics of resistance to tan spot of wheat

\begin{tabular}{|c|c|c|c|c|c|}
\hline \multirow[b]{2}{*}{ Wheat cultivar } & \multirow[b]{2}{*}{ Growth habit } & \multirow[b]{2}{*}{ Origin } & \multicolumn{2}{|c|}{ Reaction to $P$. tritici-repentis ${ }^{\mathrm{a}}$} & \multirow[b]{2}{*}{ Pedigree } \\
\hline & & & Race 1 & Race 2 & \\
\hline Erik & Spring & USA & Resistant (1) & Resistant (1) & Kitt/2/Walron/Era \\
\hline 86ISMN2137 & Spring & CIMMYT & Resistant (2) & Resistant (2) & Not known \\
\hline Kenyon & Spring & Canada & Susceptible (4-5) & Susceptible (4-5) & Neepawa*5/Buck Manantial \\
\hline $6 \mathrm{~B}-365$ & Winter & Lebanon & Susceptible (4-5) & Resistant (1-2) & Not known \\
\hline Red Chief & Winter & USA & Resistant (1) & Resistant (1) & Red Clawson/Red Arcadian \\
\hline
\end{tabular}

\footnotetext{
${ }^{\text {a }}$ Rating scale ( 1 to 5 ) based on lesion type where $1=$ resistant and $5=$ fully susceptible (20).

b Glenlea is susceptible to necrosis but resistant to chlorosis induced by race 1 .
} 
$\mathrm{F}_{2}$ generation fitted a 1 resistant/3 susceptible ratio and the $\mathrm{F}_{2: 3}$ families of these crosses segregated in a 1 homozygous resistant/ 2 segregating/1 homozygous susceptible ratio indicating that a single recessive gene controlled resistance (Tables 2 and 3).

$\mathrm{F}_{1}$ plants of the cross Glenlea/6B-365 showed only necrotic symptoms indicating that resistance to the chlorosis component and to the necrosis component caused by race 1 was dominant and recessive, respectively (Table 2). Since rating of individual plants for resistance to both necrosis and chlorosis was difficult, plants were rated for the presence or absence of necrosis and/or chlorosis. The $\mathrm{F}_{2}$ generation segregated in a 3:13 (absence/presence) ratio (Table 2). The $\mathrm{F}_{2: 3}$ families segregated in a 1 homozygous resistant (necrosis and chlorosis)/8 segregating (necrosis and/or chlorosis)/7 homozygous susceptible (necrosis and/or

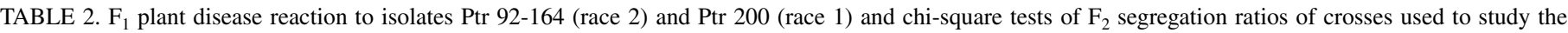
inheritance and allelic relationships among the gene(s) controlling resistance to necrosis caused by races 1 and 2

\begin{tabular}{|c|c|c|c|c|c|c|c|}
\hline \multirow[b]{2}{*}{ Cross } & \multicolumn{2}{|c|}{$\mathrm{F}_{1}$ plants $^{\mathrm{a}}$} & \multicolumn{2}{|c|}{$\mathrm{F}_{2}$ plants $^{\mathrm{a}}$} & \multirow[b]{2}{*}{ Ratio tested } & \multirow[b]{2}{*}{$\chi^{2}$ value } & \multirow{2}{*}{$\begin{array}{c}\text { Probability } \\
\text { value }^{\mathrm{b}}\end{array}$} \\
\hline & $\mathrm{R}$ & $\mathrm{S}$ & $\mathrm{R}$ & $\mathrm{S}$ & & & \\
\hline \multicolumn{8}{|c|}{ Resistant/susceptible tested with Ptr 92-164 (race 2) } \\
\hline 86ISMN 2137/Kenyon & 0 & 9 & 102 & 255 & $1: 3$ & 2.43 & 0.12 \\
\hline Erik/Kenyon & 0 & 9 & 90 & 264 & $1: 3$ & 0.03 & 0.85 \\
\hline Red Chief/Kenyon & 0 & 9 & 72 & 254 & $1: 3$ & 1.48 & 0.22 \\
\hline Hadden/Kenyon & 0 & 8 & 95 & 305 & $1: 3$ & 0.33 & 0.56 \\
\hline 86ISMN 2137/Glenlea & 0 & 9 & 80 & 274 & $1: 3$ & 1.09 & 0.30 \\
\hline Erik/Glenlea & 0 & 9 & 96 & 256 & $1: 3$ & 0.97 & 0.33 \\
\hline Red Chief/Glenlea & 0 & 9 & 112 & 320 & $1: 3$ & 0.20 & 0.65 \\
\hline Hadden/Glenlea & 0 & 8 & 92 & 248 & $1: 3$ & 0.77 & 0.38 \\
\hline \multicolumn{8}{|c|}{ Susceptible/susceptible tested with Ptr 92-164 (race 2) } \\
\hline Kenyon/Glenlea & 0 & 9 & 0 & 340 & $0: 1$ & $\ldots$ & $\ldots$ \\
\hline \multicolumn{8}{|c|}{ Resistant/resistant tested with Ptr 92-164 (race 2) } \\
\hline Erik/86ISMN 2137 & 9 & 0 & 315 & $7^{\mathrm{c}}$ & $15: 1$ & 9.13 & $<0.01$ \\
\hline Erik/Hadden & 8 & 0 & 338 & $5^{c}$ & $15: 1$ & 13.44 & $<0.01$ \\
\hline Erik/Red Chief & 8 & 0 & 311 & $9^{c}$ & $15: 1$ & 6.45 & 0.01 \\
\hline 86ISMN 2137/Hadden & 9 & 0 & 312 & $8^{c}$ & $15: 1$ & 7.68 & $<0.01$ \\
\hline 86ISMN 2137/Red Chief & 8 & 0 & 336 & $3^{c}$ & $15: 1$ & 16.65 & $<0.01$ \\
\hline Hadden/Red Chief & 8 & 0 & 308 & $13^{\mathrm{c}}$ & $15: 1$ & 2.65 & 0.10 \\
\hline \multicolumn{8}{|c|}{ Resistant/susceptible tested with Ptr 200 (race 1) } \\
\hline Erik/Glenlea & 0 & 9 & 94 & 266 & $1: 3$ & 0.24 & 0.63 \\
\hline Hadden/Glenlea & 0 & 9 & 54 & 252 & $1: 3$ & 0.74 & 0.39 \\
\hline \multicolumn{8}{|c|}{ Susceptible/susceptible tested with Ptr 200 (race 1) } \\
\hline Glenlea/6B-365 & 0 & 8 & 54 & 252 & $3: 13$ & 0.24 & 0.88 \\
\hline
\end{tabular}

${ }^{a} \mathrm{R}=$ resistant (ratings of 1 to 2 ), $\mathrm{S}=$ susceptible (ratings of 3 to 5 ).

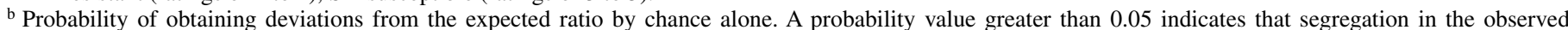
population does not differ significantly from the expected ratio.

c Reaction was moderately susceptible (rating of 3 ).

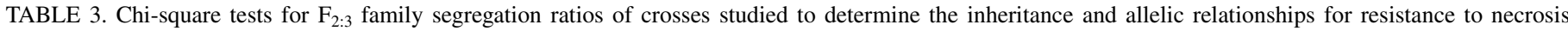
caused by Ptr 92-164 (race 2) and Ptr 200 (race 1)

\begin{tabular}{|c|c|c|c|c|c|c|}
\hline \multirow[b]{2}{*}{ Cross } & \multicolumn{3}{|c|}{$\mathrm{F}_{2: 3}$ family reaction } & \multirow[b]{2}{*}{ Ratio tested } & \multirow[b]{2}{*}{$\chi^{2}$ value } & \multirow{2}{*}{$\begin{array}{c}\text { Probability } \\
\text { value }^{\mathrm{d}}\end{array}$} \\
\hline & Resistant $^{\mathrm{a}}$ & Segregating $^{\mathrm{b}}$ & Susceptible $^{c}$ & & & \\
\hline \multicolumn{7}{|c|}{ Resistant/susceptible tested with Ptr 92-164 (race 2) } \\
\hline 86ISMN 2137/Kenyon & 27 & 56 & 37 & $1: 2: 1$ & 2.20 & 0.33 \\
\hline Erik/Kenyon & 28 & 60 & 32 & $1: 2: 1$ & 0.27 & 0.88 \\
\hline Red Chief/Kenyon & 23 & 61 & 36 & $1: 2: 1$ & 2.85 & 0.24 \\
\hline Hadden/Kenyon & 26 & 61 & 33 & $1: 2: 1$ & 0.85 & 0.65 \\
\hline 86ISMN 2137/Glenlea & 28 & 54 & 38 & $1: 2: 1$ & 2.87 & 0.24 \\
\hline Erik/Glenlea & 31 & 55 & 34 & $1: 2: 1$ & 0.98 & 0.61 \\
\hline Red Chief/Glenlea & 25 & 64 & 31 & $1: 2: 1$ & 1.13 & 0.57 \\
\hline Hadden/Glenlea & 28 & 63 & 29 & $1: 2: 1$ & 0.32 & 0.85 \\
\hline \multicolumn{7}{|c|}{ Susceptible/susceptible tested with Ptr 92-164 (race 2) } \\
\hline Kenyon/Glenlea & 0 & $\ldots$ & 40 & $0: 1$ & $\ldots$ & $\ldots$ \\
\hline \multicolumn{7}{|c|}{ Resistant/resistant tested with Ptr 92-164 (race 2) } \\
\hline Erik/86ISMN 2137 & 40 & $\ldots$ & 0 & $1: 0$ & $\ldots$ & $\ldots$ \\
\hline Erik/Hadden & 40 & $\ldots$ & 0 & $1: 0$ & $\ldots$ & $\ldots$ \\
\hline Erik/Red Chief & 40 & $\ldots$ & 0 & $1: 0$ & $\ldots$ & $\ldots$ \\
\hline 86ISMN 2137/Hadden & 40 & $\ldots$ & 0 & $1: 0$ & $\ldots$ & $\ldots$ \\
\hline 86ISMN 2137/Red Chief & 40 & $\ldots$ & 0 & $1: 0$ & $\ldots$ & $\ldots$ \\
\hline \multicolumn{7}{|c|}{ Resistant/susceptible tested with Ptr 200 (race 1) } \\
\hline Erik/Glenlea & 26 & 53 & 21 & $1: 2: 1$ & 0.86 & 0.65 \\
\hline Hadden/Glenlea & 26 & 36 & 18 & $1: 2: 1$ & 2.40 & 0.30 \\
\hline \multicolumn{7}{|c|}{ Susceptible/susceptible tested with Ptr 200 (race 1) } \\
\hline 6B-365/Glenlea & 3 & 33 & 24 & $1: 8: 7$ & 0.64 & 0.73 \\
\hline
\end{tabular}

a Family has individuals expressing a resistant reaction (ratings of 1 to 2).

${ }^{\mathrm{b}}$ Family is segregating for resistant and susceptible reactions.

${ }^{\mathrm{c}}$ Family has individuals expressing a susceptible reaction (ratings of 3 to 5).

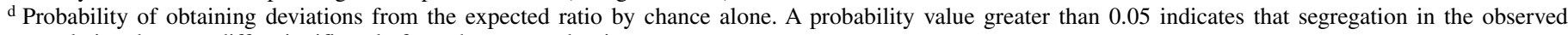
population does not differ significantly from the expected ratio. 
chlorosis) ratio (Table 3). These ratios can be explained by the presence of two independent genes controlling resistance to race 1 in the cross Glenlea/6B-365, a recessive gene for resistance to the necrosis component contributed by 6B-365 and a dominant gene for resistance to the chlorosis component contributed by Glenlea.

Relationship between genes controlling resistance to necrosis caused by races 1 and $2 . F_{2: 8}$ lines of the $R / S$ cross Erik/Glenlea were tested with isolates Ptr 200 (race 1) and Ptr 92164 (race 2) to study the relationship between the single recessive genes controlling resistance to necrosis caused by race 1 and race 2 . When tested with race 1 and with race 2 , segregation of $F_{2: 8}$ lines of the cross Erik/Glenlea fitted the ratio of 63 homozygous resistant/2 segregating/63 homozygous susceptible, as expected for single-gene control (Table 5).

These genes controlling resistance to the necrosis induced by race 1 and race 2 were not independent (Table 5). Forty lines were resistant to both isolates Ptr 92-164 (race 2) and Ptr 200 (race 1) and 37 lines were susceptible to both isolates. Two lines segregated for resistance to both isolates and one line was susceptible to isolate Ptr 92-164 but segregated for resistance to isolate Ptr 200. All but one line gave similar disease reactions to isolates Ptr 200 (race 1) and Ptr 92-164 (race 2). This indicated that the same gene controlled resistance to necrosis caused by race 1 and by race 2 .

\section{DISCUSSION}

Throughout this study, a single recessive gene was found to control resistance to the necrosis component of tan spot. A similar finding has also been reported by others $(7-9,18,21,23)$. Duguid (7) observed that the $F_{2}$ segregation in cross Erik/Katepwa fitted a 5 resistant/11 susceptible ratio, while in cross Erik/BH1146, the $\mathrm{F}_{2}$ segregation ratio was 1 resistant/3 susceptible. However, the $\mathrm{F}_{2: 3}$ family segregation for both crosses indicated single gene control. In this study, crosses involving resistant genotype Erik segregated for single gene control, also reported by Lamari and Bernier (21). These differing results demonstrate the undesirability of basing segregation data for tan spot on single plant ratings. Single plant data are useful to derive preliminary results but misclassification or disease escape can cause incorrect genetic interpretation. These results should be verified by family segregation data, which is less liable to such errors.

In this study, plants of crosses involving resistant winter wheat cultivars were not vernalized, resulting in loss of winter-habit families in the $F_{3}$ and later generations. If linkage between genes for vernalization and resistance to necrosis existed, the segregation patterns observed in the inheritance study of crosses involving spring and winter cultivars would be different from those involving only spring wheat. This was not observed and indicated that the resistance gene was not linked to genes for vernalization. These results also indicated that the same recessive gene for resistance was present in both spring and winter resistant cultivars and that this gene controlled resistance to necrosis caused by race 1 and by race 2 .

Preliminary studies by Anderson et al. (4) suggested that the same recessive gene controlled resistance to necrosis in both durum and common wheat. Based on results from this study and from that of Anderson et al. (4), it is hypothesized that resistance

TABLE 4. Chi-square tests of $\mathrm{F}_{2: 4}$ family segregation ratios of crosses used to study the inheritance of resistance to necrosis caused by Ptr 92-164 (race 2)

\begin{tabular}{|c|c|c|c|c|c|c|}
\hline \multirow[b]{2}{*}{ Cross } & \multicolumn{3}{|c|}{$\mathrm{F}_{2: 4}$ family reaction } & \multirow[b]{2}{*}{ Ratio tested } & \multirow[b]{2}{*}{$\chi^{2}$ value } & \multirow[b]{2}{*}{ Probability value $^{\mathrm{d}}$} \\
\hline & Resistant $^{\mathrm{a}}$ & Segregating $^{\mathrm{b}}$ & Susceptible $^{c}$ & & & \\
\hline 86ISMN 2137/Kenyon & 33 & 24 & 23 & $3: 2: 3$ & 2.73 & 0.25 \\
\hline Erik/Kenyon & 29 & 23 & 28 & $3: 2: 3$ & 0.62 & 0.73 \\
\hline Red Chief/Kenyon & 27 & 24 & 29 & $3: 2: 3$ & 1.13 & 0.57 \\
\hline Hadden/Kenyon & 26 & 23 & 31 & $3: 2: 3$ & 1.02 & 0.60 \\
\hline 86ISMN 2137/Glenlea & 24 & 22 & 34 & $3: 2: 3$ & 1.95 & 0.38 \\
\hline Erik/Glenlea & 25 & 23 & 32 & $3: 2: 3$ & 1.40 & 0.50 \\
\hline Red Chief/Glenlea & 29 & 25 & 26 & $3: 2: 3$ & 1.82 & 0.40 \\
\hline Hadden/Glenlea & 34 & 33 & 23 & $3: 2: 3$ & 2.62 & 0.27 \\
\hline
\end{tabular}

a Family has individuals expressing a resistant reaction (ratings of 1 to 2).

${ }^{\mathrm{b}}$ Family is segregating for resistant and susceptible reactions.

c Family has individuals expressing a susceptible reaction (ratings of 3 to 5).

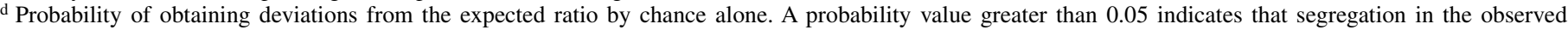
population does not differ significantly from the expected ratio.

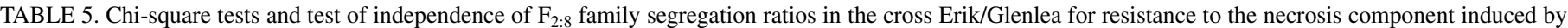
isolates Ptr 92-164 (race 2) and Ptr 200 (race 1)

\begin{tabular}{|c|c|c|c|c|c|c|}
\hline \multirow[b]{2}{*}{ Isolate } & \multicolumn{3}{|c|}{$\mathrm{F}_{2: 8}$ families } & \multirow[b]{2}{*}{ Ratio tested } & \multirow[b]{2}{*}{$\chi^{2}$ value } & \multirow[b]{2}{*}{ Probability value $^{\mathrm{d}}$} \\
\hline & Resistant $^{\mathrm{a}}$ & Segregating ${ }^{\mathrm{b}}$ & Susceptible $^{c}$ & & & \\
\hline Ptr 92-164 & 40 & 2 & 38 & $63: 2: 63$ & 0.51 & 0.78 \\
\hline Ptr 200 & 40 & 3 & 37 & $63: 2: 63$ & 2.60 & 0.27 \\
\hline
\end{tabular}

\begin{tabular}{|c|c|c|c|c|c|c|c|}
\hline & & & 92-1 & & & & \\
\hline & & $\mathrm{R}_{2}$ & $\mathrm{Seg}_{2}$ & $\mathrm{~S}_{2}$ & & & \\
\hline Ptr 200 & $\begin{array}{l}\mathrm{R}_{1} \\
\mathrm{Seg}_{1} \\
\mathrm{~S}_{1}\end{array}$ & $\begin{array}{r}40 \\
0 \\
0\end{array}$ & $\begin{array}{l}0 \\
2 \\
0\end{array}$ & $\begin{array}{r}0 \\
1 \\
37\end{array}$ & R.T.e & 276.63 & 0.00 \\
\hline
\end{tabular}

${ }^{a}$ Family has individuals expressing a resistant reaction (ratings of 1 to 2).

${ }^{\mathrm{b}}$ Family is segregating for resistant and susceptible reactions.

${ }^{\mathrm{c}}$ Family has individuals expressing a susceptible reaction (ratings of 3 to 5).

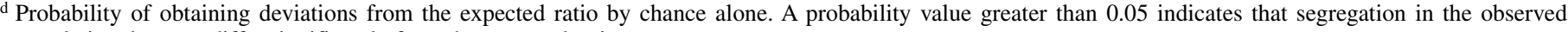
population does not differ significantly from the expected ratio.

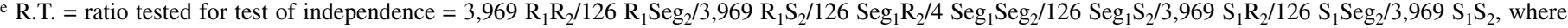
$R_{1}$ and $R_{2}=$ resistant to race 1 and race 2, respectively; Seg and $S_{1} g_{2}=$ segregating to race 1 and race 2 , respectively; and $S_{1}$ and $S_{2}=$ susceptible to race 1 and race 2 , respectively. 
to necrosis caused by race 1 and race 2 in both durum and common wheat is controlled by the same single gene. This suggests that the genetic base for resistance to the necrosis component of tan spot is narrow. The relationship of this resistance gene to tsn 1 $(12,30)$ is not known since both studies involved genotypes different to those used in this study. However, since this and other studies have shown this resistance gene to be widespread in the common wheat gene pool, it is likely that the recessive gene identified in this study is also tsn1.

A few moderately susceptible plants (rating 3) were observed in the $F_{2}$ generation of the $R / R$ crosses. These moderately susceptible plants were not progeny tested, but testing of random $F_{2: 3}$ families showed that all families were homozygous resistant, thus confirming that the resistant parents possessed the same resistance gene. Although $F_{2}$ segregation data indicated that Hadden and Red Chief possessed different genes for resistance, $F_{2: 3}$ families of crosses Erik/Hadden and Erik/Red Chief failed to segregate indicating the presence of the same resistance gene in Erik, Hadden, and Red Chief. These conflicting results are viewed as further evidence of the unreliability of single plant segregation data. However, these few moderately susceptible plants could be expected if a cluster of tightly linked resistance genes existed. The population sizes used in this study were not large enough to conclusively identify the moderately susceptible plants as rare recombinants and thus the presence of such a cluster.

Lamari et al. (25) believe that the wheat- $P$. tritici-repentis pathosystem is an example of the toxin model originally proposed by Ellingboe (11). In this model, a mirror image of the classical gene-for-gene model of host-pathogen interaction (16), a compatible interaction between host plant and pathogen, leads to susceptibility, the result of the presence of a "toxin-receptor" site in the host. If such a site is considered the product of a susceptibility gene, resistance in the wheat $-P$. tritici-repentis pathosystem could be viewed as due to absence of a susceptibility gene rather than presence of a resistance gene. Resistance would be expected to be lost when a mutation in the host results in production of the receptor site or the pathogen produces a new toxin which would be recognized by a different receptor site in the host.

This suggests that the fact that only one gene has been identified for resistance to necrosis caused by race 1 and race 2 does not necessarily imply that the resistance caused by this gene will be short-lived. Both race 1 and race 2 produce the necrosisinducing toxin Ptr ToxA (21), which would have a specific host receptor site. Absence of this site would result in resistance which to be defeated would require the pathogen to produce a new toxin, a gain of function. Gain of a function, which did not exist before, is usually associated with the occurrence of a back mutation, normally a much less common event than forward mutations which are usually associated with loss of function. A similar type of mutation in the resistant host would be needed to produce a receptor site for Ptr ToxA. Since either mutation event would be rare, use of this resistance gene in breeding tan spot-resistant cultivars is unlikely to result in the occurrence of new virulent races and subsequent breakdown of resistance.

Genotype 6B-365 is resistant to the necrosis and susceptible to the chlorosis induced by race 1 . When tested with isolate Ptr 200 (race 1), the segregation data for cross Glenlea/6B-365 indicated that resistance was due to two independent genes. However, in crosses Erik/Glenlea and Hadden/Glenlea, which segregated for the necrosis component only, resistance to race 1 was controlled by a single gene. Therefore, depending on whether a cross was segregating for one or both components of the tan spot disease syndrome, resistance to race 1 would appear to be controlled by either one or two genes.

Because this pathosystem follows the toxin model, development of wheat cultivars resistant to all known races requires selection against those host susceptibility genes which result in a compatible reaction. For resistance to the necrosis component in common wheat, this involves selection against the susceptibility genes related to three groups of races of $\tan$ spot, races $1,2,7$, and 8 (25), race $10(2)$, and race 11 (26). In durum wheat, necrosis-inducing races 3,5 , and 6 also must be considered. To ensure that this selection proceeds efficiently, the racial structure of the pathogen population should be monitored on a regular basis. As well, a pre-emptive breeding strategy should be considered (27). Race 5, initially identified in North Africa (24), has recently been found in North America $(1,31)$. Recently identified races 9 and 10, from South America, possess virulence not yet found in the current North American races $(2,3)$ and could be used in confined tests of North American cultivars and breeding material to identify sources of resistance.

\section{ACKNOWLEDGMENTS}

This research was part of a Ph.D. thesis submitted by P. K. Singh to the College of Graduate Studies and Research, University of Saskatchewan. Financial support was provided by a University of Saskatchewan Graduate Scholarship and the Saskatchewan Agriculture Development Fund.

\section{LITERATURE CITED}

1. Ali, S., and Francl, L. J. 1999. Races of Pyrenophora tritici-repentis on durum wheat in the northern Great Plains of the U.S. (Abstr.) Phytopathology 89(suppl.):S2.

2. Ali, S., and Francl, L. 2002. A new race of Pyrenophora tritici-repentis from Brazil. Plant Dis. 86:1050.

3. Ali, S., Ling, H., Meinhardt, S., and Francl, L. 2002. A new race of Pyrenophora tritici-repentis that produces a putative host-selective toxin. (Abstr.) Phytopathology 92(suppl.):S3.

4. Anderson, J. A., Effertz, R. J., Faris, J. D., Francl, L. J., Meinhardt, S. W., and Gill, B. S. 1999. Genetic analysis of sensitivity to a Pyrenophora tritici-repentis necrosis-inducing toxin in durum and common wheat. Phytopathology 89:293-297.

5. Ciuffetti, L. M., and Tuori, R. P. 1999. Advances in the characterization of the Pyrenophora tritici-repentis-wheat interaction. Phytopathology 89: 444-449.

6. De Wolf, E. D., Effertz, R. J., Ali, S., and Jordahl, J. G. 1998. Vistas of tan spot research. Can. J. Plant Pathol. 20:349-370.

7. Duguid, S. D. 1995. Genetics of resistance to Pyrenophora tritici-repentis (Died) Drechs. in hexaploid wheat (Triticum aestivum L.). Ph.D. thesis. The University of Manitoba, Winnipeg, Canada.

8. Duguid, S. D., and Brûlé-Babel, A. L. 2001. Inheritance of resistance to a necrosis- and chlorosis-inducing isolate from race 1 of Pyrenophora tritici-repentis in spring wheat. Can. J. Plant Sci. 81:519-525.

9. Duguid, S. D., and Brûlé-Babel, A. L. 2001. Inheritance and interaction of spring wheat (Triticum aestivum L.) resistance to race 2 and race 3 of Pyrenophora tritici-repentis (Died.) Drechs. Can. J. Plant Sci. 81: 527-533.

10. Elias, E., Cantrell, R. G., and Horsford, R. M., Jr. 1989. Heritability of resistance to tan spot in durum wheat and its association with other agronomic traits. Crop Sci. 29:299-304.

11. Ellingboe, A. H. 1976. Genetics of host-parasite interactions. Pages 761778 in: Encyclopedia of Plant Physiology. Vol. 4. Physiological Plant Pathology. R. Heitefuss and P. H. Williams, eds. Springer-Verlag, New York.

12. Faris, J. D., Anderson, J. A., Francl, L. J., and Jordahl, J. G. 1996. Chromosomal location of a gene conditioning insensitivity in wheat to a necrosis-inducing culture filtrate from Pyrenophora tritici-repentis. Phytopathology 86:459-463.

13. Faris, J. D., Anderson, J. A., Francl, L. J., and Jordahl, J. G. 1997. RFLP mapping of resistance to chlorosis induction by Pyrenophora triticirepentis. Theor. Appl. Genet. 94:98-103.

14. Fernandez, M. R., DePauw, R. M., Clarke, J. M., and Fox, S. L. 1998. Discoloration of wheat kernels by Pyrenophora tritici-repentis. Can. J. Plant Pathol. 20:380-383.

15. Fernandez, M. R., McConkey, B. G., and Zentner, R. P. 1998. Tillage and summer fallow effects on leaf spot diseases of wheat in the semiarid Canadian Prairies. Can. J. Plant Pathol. 20:376-379.

16. Flor, H. H. 1955. Host-parasite interactions in flax rust-Its genetics and other implications. Phytopathology 45:680-685.

17. Gamba, F. M., and Lamari, L. 1998. Mendelian inheritance of resistance to tan spot (Pyrenophora tritici-repentis) in selected genotypes of durum wheat (Triticum turgidum). Can. J. Plant Pathol. 20:408-414. 
18. Gamba, F. M., Lamari, L., and Brule-Babel, A. 1998. Inheritance of racespecific necrotic and chlorotic reactions induced by Pyrenophora triticirepentis in hexaploid wheats. Can. J. Plant Pathol. 20:401-407.

19. Hanson, W. D. 1959. Minimum family sizes for the planning of genetic experiments. Agron. J. 51:711-715.

20. Lamari, L., and Bernier, C. C. 1989. Evaluation of wheat lines and cultivars to tan spot (Pyrenophora tritici-repentis) based on lesion type. Can. J. Plant Pathol. 11:49-56.

21. Lamari, L., and Bernier, C. C. 1989. Toxin of Pyrenophora triticirepentis: Host specificity, significance in disease, and inheritance of host reaction. Phytopathology 79:740-744.

22. Lamari, L., and Bernier, C. C. 1989. Virulence of isolates of Pyrenophora tritici-repentis on 11 wheat cultivars and cytology of differential host reactions. Can. J. Plant Pathol. 11:284-290.

23. Lamari, L., and Bernier, C. C. 1991. Genetics of tan necrosis and extensive chlorosis in tan spot of wheat caused by Pyrenophora tritici-repentis. Phytopathology 81:1092-1095.

24. Lamari, L., Sayoud, R., Boulif, M., and Bernier, C. C. 1995. Identification of a new race in Pyrenophora tritici-repentis: Implications for the current pathotype classification system. Can. J. Plant Pathol. 17:312-318.

25. Lamari, L., Strelkov, S. E., Yahyaoui, A., Orabi, J., and Smith, R. B. 2003.
The identification of two new races of Pyrenophora tritici-repentis from the host center of diversity confirms a one-to-one relationship in tan spot of wheat. Phytopathology 93:391-396.

26. Manning, V. A., Pandelova, I., and Ciuffetti, L. M. 2002. A race for a novel host-selective toxin. (Abstr.) Phytopathology 92(suppl.):S51.

27. McIntosh, R. A. 1992. Pre-emptive breeding to control wheat rusts. Euphytica 63:103-113.

28. Nagle, B. J., Frohberg, R. C., and Hosford, R. M., Jr. 1982. Inheritance of resistance to tan spot of wheat. Pages 40-45 in: Tan Spot of Wheat and Related Diseases Workshop. R. M. Hosford Jr., ed. North Dakota State University, Fargo.

29. Shabeer, A. 1986. I. Inheritance of tan spot resistance in the winter wheat cultivar Red Chief. II. Growth stage effects on losses in yield and yield components from tan spot of winter wheat. Ph.D. thesis. Kansas State University, Manhattan.

30. Stock, W. S., Brule-Babel, A. L., and Penner, G. A. 1996. A gene for resistance to a necrosis-inducing isolate of Pyrenophora tritici-repentis located on 5BL of Triticum aestivum cv. Chinese Spring. Genome 39:598-604.

31. Strelkov, S. E., Lamari, L., Sayoud, R., and Smith, R. B. 2002. Comparative virulence of chlorosis-inducing races of Pyrenophora tritici-repentis. Can. J. Plant Pathol. 24:29-35. 